Technological University Dublin

DÜBLIN

ARROW@TU Dublin

\title{
Reflections on a Decade of Global Rankings: What We've Learned and Outstanding Issues.
}

\author{
Ellen Hazelkorn \\ Technological University Dublin, ellen.hazelkorn@tudublin.ie
}

Follow this and additional works at: https://arrow.tudublin.ie/cserart

Part of the Educational Sociology Commons

\section{Recommended Citation \\ Hazelkorn, E. (2014) Reflections on a Decade of Global Rankings: what we've learned and outstanding issues. European journal of education, vol. 49, no. 1, March. doi:10.1111/ejed.12059}

This Article is brought to you for free and open access by the Centre for Social and Educational Research at ARROW@TU Dublin. It has been accepted for inclusion in Articles by an authorized administrator of ARROW@TU Dublin. For more information, please contact arrow.admin@tudublin.ie, aisling.coyne@tudublin.ie, gerard.connolly@tudublin.ie.

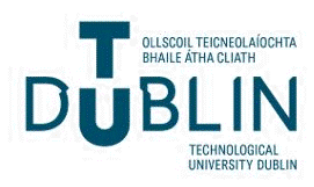




\title{
Reflections on a Decade of Global Rankings: what we've learned and outstanding issues ${ }^{\star}$
}

\author{
Ellen Hazelkorn
}

\section{The World is Watching}

Ten years have passed since the Shanghai Jiao Tong University first published the Academic Ranking of World Universities ( $A R W U$ ) in 2003. Followed shortly thereafter by the Times Higher Education QS Top University Ranking (THE-QS) in 2004, the arrival of rankings has been a game-changer for higher education and research, intensifying cross-national comparisons. They immediately attracted the attention of policymakers and the academy, challenging perceived wisdom about the status and reputation, as well as quality and performance, of higher education institutions $\left(\mathrm{HEIs}^{1}\right)$. The Irish Minister for Education and Science, speaking in his capacity as President of the European Council, echoed the concerns of many political and academic leaders:

Last year the Shanghai Jiao Tong University's Institute of Education ranked the world's top 500 universities on academic and research performance. For the European Union, the news is not all that good. The study shows that 35 of the top 50 Universities in the world are American ... (Dempsey, 2004).

Almost ten years later, at the launch of Europe 2020, unease was just as palpable:

Europe is no longer setting the pace in the global race for knowledge and talent, while emerging economies are rapidly increasing their investment in higher education (Europa, 2011, p. 2).

The arrival of global rankings coincided with a Zeitgeist of modernising higher education, and ideological and public support for markets; their continuing influence is a manifestation of the intensification of global competitiveness and their visibly multi-polar character.

Despite volumes of criticism and commentary, and some boycotts by HEIs, rankings have become an increasingly popular way to compare higher education performance and productivity. Their legacy is evident in the way they have become an implicit, and often explicit, reference point for policy-making and decisionmaking and have reinforced an evaluative state's over-reliance on quantitative indicators to measure quality. They are embedded in popular discourse and have informed behaviour, positively and perversely, of many stakeholders, both within and outside the academy. But, rankings have also produced their antithesis in the form of alternatives; importantly, they have sparked a world-wide conversation about the role, value and contribution of higher education.

Set against significant changes in the world economy, this article will reflect on three inter-related issues arising from the growing interest in and use of $\mathrm{HE}$ rankings, what they measure, and the way in which different stakeholders have

*This is a shortened version of an article originally published: Beitraege zur Hochschulforschung, February 2013. 
responded to them. There are three main sections. The first considers the way rankings have heightened policy and investment interest in higher education. The second considers whether the modifications to rankings have resolved some of the questions about what they measure, and the third looks at how rankings have influenced stakeholder behaviour. Finally, the article will reflect on what we have learned and some outstanding issues.

\section{Rankings and the World Order}

Since global rankings first appeared in 2003, the following years have borne witness to a dramatic transformation in the fortunes of the world economy and its citizens. The early years of the 'noughties' were associated with the tail-end of a long period of economic growth driven by unregulated finance capital, while the latter years have been marked by the lingering effects of the 2008 global financial crisis which plunged most developed economies into recession. In contrast with the steepest decline in growth in 60 years across OECD countries (OECD, 2009), growth in developing countries and economies in transition, in Latin America and Asia, such as Brazil, China and India, has been particularly robust in both absolute and relative terms, even if there has been some slackening in recent months. Although future growth is likely to be below the $7.5 \%$ achieved in 2010 , developing countries will continue to 'stoke the engine of the world economy, growing on average by $5.6 \%$ in 2012 and $5.9 \%$ in 2013 in the baseline outlook' (UN, 2011 a, p. 2). These developments are leading to noticeable shifts in the world order and intensification of competition between nations for a greater share of mobile investment capital and talent, raising the profile of knowledge-intense industries, including higher education.

The rise of new economic powers has been driven by a rapid structural transformation of their societies and economies, led by shifts from natural resource-based primary production to more sophisticated, skill- and technologyintensive activities. This is mirrored by significant demographic change. While the world population is ageing and the fertility rate slowing, it is still projected to reach 9.3 billion by 2050 , an increase of 2.3 billion over 2011 , equivalent to the combined populations of China and India. Most of this growth will be in developing countries (UN, 2011, p. 1). These patterns are responsible for a surging demand for higher education; according to UNESCO, there are almost 160 million students enrolled worldwide in higher education today compared with only 30 million in 1970 (UNESCO, 2009, p. 9). The overall global demand for places in higher education will peak at 263 million in 2025; India's demand will rise from 9.6 million to 61 million while China's will rise from 8 million to 45 million (Böhm et al., 2002). To meet this escalating demand, one sizeable new university will need to open every week over the next decades (Daniel, 1996).

Investment in higher education and research and development (R\&D) is now widely recognised as vital for providing the knowledge base essential for economic growth, and now recovery. Societies best able to invest heavily, especially in the bio-sciences and technology, are poised to make the greatest gains in the future; many of these entrants are emerging societies. OECD data on R\&D expenditures show China and South Africa spending more as a percentage of the gross domestic product (GDP) over the last 10 years. China was the world's second largest R\&D spender in 2009 and South Korea's trajectory starting ten years ago is also very impressive. They are now spending more than any other country on $\mathrm{R} \& \mathrm{D}$ as a 
percentage of GDP. The EU is planning to spend over 70 billion EUR through its Horizon 2020 programme between 2014 and 2020. Nonetheless, it has predicted that Brazil, Russia, India, and China would dominate future R\&D growth, overwhelming Europe and Japan and eventually matching US investment. At current levels of trend-expenditure, China will match EU-27 spending on R\&D by 2018 and US spending by 2022 (Ritzen, 2010, pp. 37-70). Brazil has a balance sheet four times that of the World Bank and India is also investing heavily (Leahy, 2012, p. 7). This reflects a deliberate national strategy by, inter alia, China, Singapore, Malaysia, South Korea and the Gulf countries to become important educational and research hubs in their area of influence (Knight, 2011), challenging the US and Europe (Knobel, 2011, p. 2).

Given the changing dynamics of the world economy, the quality and status of HEIs and university-based research have become vital indicators of competitiveness. This explains why global rankings have assumed such significance at a geo-political level. Academic rankings are often trumpeted as providing better and informed student choice, but the attention now being given to rankings by policymakers and other decision-makers indicates that, in reality, they are much more about geo-political positioning, by nations and HEIs. Around the world, rankings consciousness has risen sharply, in response to globalisation and the worldwide 'battle for excellence'. This is apparent in the way the comparative and competitive strength of nations and institutions - the knowledge world order - is projected. Developed nations and established universities in the US and Europe continue to be the primary 'winners' in the rankings race with relatively little movement among the top 25, but the pervasiveness of focusing on the top institutions obscures the changing geography of academic activity (see Table I; Hazelkorn, 2013a). Latin America, Africa and the Middle East have only a few universities amongst the top 500; Sub-Saharan African gains have been made only by historically white institutions from South Africa; and within the Middle East, only Israel regularly succeeds. However, Asian societies, most notably China, are beginning to make an appearance due to a combination of government investment strategies and changes in ranking methodology (Sharma, 2010; Lau, 2012; Li et al., 2011). When measured against population size, smaller countries, notably Hong Kong and Singapore, are doing particularly well (QS, 2013b). These trends have sharpened in recent years, although this does depend on which ranking is being used.

Despite the chorus of criticism about what rankings measure, they have succeeded in putting higher education within a wider comparative and international framework. This has challenged self-perceptions of greatness at the national, institutional and individual faculty level. Quality and excellence are now the key differentiators in the national and global markets; accordingly, there is a wide acceptance, reluctantly perhaps, that measuring and comparing academic performance and productivity are sine-qua-non underpinning quality. Winning and maintaining support for higher education, especially for institutions dependent upon the public exchequer, are key components of this process. This has all helped to push higher education, including investment levels and discussion about its contribution and impact on/for the economy, up the political and policy agenda in both developing and developed societies. As a consequence, rankings are spoken about in overtly geo-political language. Billal (n.d. 2), for example, argues that 'the size and strength of higher education systems are determined by possession of world class universities which are considered [a] more powerful asset for a nation 
4 European Fournal of Education

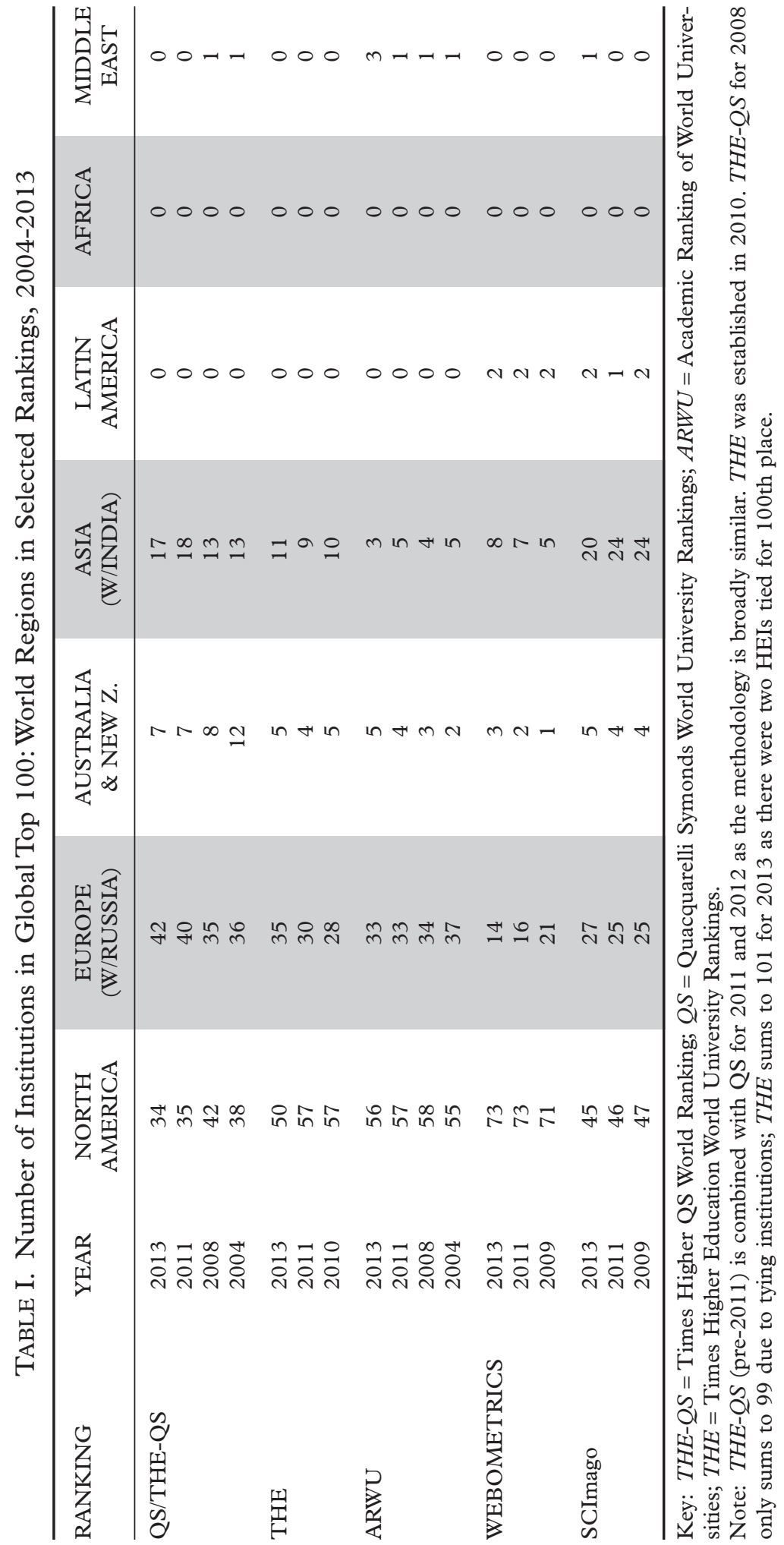


than possession of weapon[s] of mass destruction'. Similarly, the Russian Minister for Education said rankings were an 'instrument of competitive battle and influence' (Kishkovsky, 2012; also Silverstein \& Singhi, 2012; Anon, 2012; ABS-CBN News, 2012; Marszal, 2012). Rankings chronicle changes in the world polity symbolised by the G8 being overshadowed by the G20 and China coming to the aid of the EU financial crisis (Alderman \& Barboza, 2011; Wade, 2011) — in which different world regions vying for prominence in a complex, multi-polar world have replaced the previous binary Cold War.

\section{Measuring What's Meaningful}

When ARWU first appeared in 2003, the higher education world was caught unawares. US News and World Report (USNWR) had been producing college rankings since 1983, but it was a US phenomenon for a society in which higher education was a commodity and students were relatively mobile. Even for students who remained within their own city or state, the variety of institutional choices encouraged a consumerist approach to decision-making. But, ARWU foreshadowed an entirely new set of circumstances, where international or crossjurisdictional comparisons would become the norm. Today, global rankings have become the simple (and simplistic) tool of choice for a wide range of stakeholders on the presumption that they provide a good measure of quality. They have become big business for the media organisations and a business opportunity for others.

The history of rankings can be divided into three main periods:

Phase 1: The origin of rankings dates back to the US and the publication of Cattell's American Men of Science (1910). Focusing on 'distinguished persons', it set the trend until the 1950s, using indicators such as faculty expertise, graduate success in later life, and academic resources. This approach effectively excluded most public universities as they were newer with a different mission than the older private universities (Webster, 1986, pp. 14, 107-19).

Phase 2: National rankings became popular after 1960. Drawing heavily on the Science and Social Sciences Citation Indexes, they focused initially on graduate institutions. This changed with the publication of USNWR in 1983, whose success over subsequent years has paralleled the transformation to near-universal higher education. Today, there is a growing number of national rankings.

Phase 3: ARWU marked the era of global rankings, and the realisation that in a global knowledge economy, national pre-eminence is no longer enough. Despite being developed to highlight the position of Chinese universities vis-a-vis competitor universities and being entirely focused on research, it has effectively become the 'gold standard'. It was followed by Webometrics, and THE-QS in 2004; the latter partnership split in 2009 giving birth to two new rankings: QS World University Rankings (2010) and THE World University Ranking, the latter partnering with Thomson Reuters (2010), thereby representing a significant entry into the market by the producer of one of the major bibliometric databases. The EU commissioned U-Multirank as a companion instrument to its U-Map classification system; a feasibility study was published in 2011 and the next phase is due in 2014. Today, there are over 10 global rankings of varying scope and influence, plus a growing number of system-level, regional, specialist and professional rankings. Of these, $A R W U$, THEWorld University Rankings, and QSWorld University Rankings are the 'big three'.

Most academic, political and stakeholder commentary and criticism have focused on how rankings measure education/academic quality by comparing 
'whole institutions', using a limited set of weighted attributes for which (internationally) comparable data are available. Quantification of performance gives the 'appearance of scientific objectivity' (Ehrenberg, 2001, p. 1), but ignores the complexity of HEIs and their different contexts and the fact that some institutions may score higher in some domains than others. It also assumes that the indicators are a meaningful measure of quality. Reputational surveys are prone to being subjective, self-referential and self-perpetuating. Bibliometric data are less reliable for the arts, humanities and social science disciplines, and there is no focus on the impact or benefit of research. Similarly, research income benefits capital-intensive bio-sciences and medicine disciplines and says little about the impact of research on teaching. No attention is given to regional or civic engagement, a major policy/mission objective for many governments and HEIs.

Over the years, new rankings have emerged and others have responded to critics by modifying their assertions (cf. Baty in Sharma, 2013) and methodologies; the latter has provoked disapproval, with critics saying it creates volatility making year-on-year comparability difficult and rankers saying it affirms they are listening to criticism. There have been changes at the level of analysis, leading to a growing number and range of specialist rankings in response to censure as much as to each other. There are rankings pitched at discipline/field of study level as well as different categories of institutions (e.g. THE 100 Under 50), world region (e.g. Asia, Latin America) or specialisation (e.g. THE Reputation Ranking, QS Best Student Cities). Another format is the QS Stars rating system; unlike rankings, universities pay to be assessed against a range of criteria and be awarded between 1-5 stars (Guttenplan, 2012). Thompson Reuters created the Global Institutional Profiles project and ARWU has its Global Research University Profiles project; both will produce a rich vein of institutional data. New ventures have also emerged, such as Smartphone apps, and a plethora of informational conferences, master classes and consultancies. THE sponsored a video competition encouraging participants to say why 'my university is world class because. .' as part of the official launch of the 2012-13 and 2013-2014 rankings; winners receive an iPad and the chance for their film to be broadcast on their website and viewed by over 30,000 in year one (THE 2012, 2013). IREG (2011) has emerged as the 'regulator' for the industry. In business parlance, these initiatives are tantamount to new product development or revitalising products in response to new market opportunities or consumer demand and feedback.

Throughout, ARWU has remained consistently focused on research, with few changes to its methodology because, as its promoters recognise:

It would be impossible to rank the quality of university education worldwide because of the huge differences of universities in the large variety of countries and the technical difficulties in obtaining internationally comparable data (Liu \& Cheng, 2005).

In contrast, THE and $Q S$ have revised their methodology several times - before and after their divorce and subsequently (Rauhvargers, 2011, 2013); nonetheless there are some clear trends. THE relies heavily on research, equivalent to $65 \%$ if research, citations, innovation and its new indicator of international publications are combined; both $T H E$ and $Q S$ emphasise reputation or peer review. The former has two separate reputational surveys: per academic for research (18\%) and for teaching (15\%) equating to $33 \%$, albeit it was $19.5 \%$ and $15 \%$, respectively, in 
2010; QS assigns 50\% of marks to institutional reputation based on surveys amongst academics (40\%) and employers (10\%). Whereas the old THE/QS ranking measured graduate employability, $Q S$ asks a select list of employers to identify universities that produce the best graduates; $T H E$ asks similar questions of academics with respect to teaching (see Table II).

TABLE II. Indicators and Weightings of Selected Rankings (2013)

\begin{tabular}{|c|c|c|c|c|c|}
\hline \multirow[t]{2}{*}{ Ranking } & \multicolumn{5}{|c|}{ Indicators and Weightings, percentage } \\
\hline & Indicator & Total & Research & Teaching & Reputation \\
\hline $\begin{array}{l}\text { Academic } \\
\text { Ranking of } \\
\text { World } \\
\text { Universities } \\
\text { (ARWU) } \\
(2003-)\end{array}$ & $\begin{array}{l}\text {-Quality of education } \\
\text { Quality of faculty } \\
\text {-No. Nobel Prize/Field Medal } \\
\text {-No. HiCi researchers } \\
\text { Research output } \\
\text {-No. articles in Nature/Science } \\
\text {-No. articles in Citation Index } \\
\text { - Size of institution }\end{array}$ & $\begin{array}{l}10 \\
20 \\
20 \\
20 \\
20 \\
10\end{array}$ & 100 & 0 & 0 \\
\hline $\begin{array}{l}\text { Times Higher } \\
\text { Education/QS } \\
\text { World University } \\
\text { Rankings } \\
\text { (THE QS) } \\
(2003-2009)\end{array}$ & $\begin{array}{l}\text {-Peer appraisal } \\
\text { - Graduate employability } \\
\text { - Teaching quality/Staff-student } \\
\text { ratio } \\
\text {-International students } \\
\text {-International faculty } \\
\text { - Research quality/Citations } \mathrm{p} \\
\text { faculty }\end{array}$ & $\begin{array}{r}40 \\
10 \\
20 \\
5 \\
5 \\
20 \\
2\end{array}$ & 60 & 20 & 10 \\
\hline $\begin{array}{l}\text { QS World } \\
\text { University } \\
\text { Rankings } \\
(2010-)\end{array}$ & $\begin{array}{l}\text {-Academic Peer Review } \\
\text {-Employer Review } \\
\text {-International Faculty Ratio } \\
\text {-International Student Ratio } \\
\text {-Student/Faculty Ratio } \\
\text { - Citations per Faculty }\end{array}$ & $\begin{array}{r}40 \\
10 \\
5 \\
5 \\
20 \\
20\end{array}$ & 20 & 20 & 50 \\
\hline $\begin{array}{l}\text { Times Higher } \\
\text { Education World } \\
\text { University } \\
\text { Ranking (THE) } \\
\text { (2010-) }\end{array}$ & $\begin{array}{l}\text { - Teaching } \\
\text { - Research } \\
\text {-Citations } \\
\text { •Economic/Innovation } \\
\text {-International Diversity }\end{array}$ & $\begin{array}{l}30 \\
30 \\
30 \\
2.5 \\
7.5\end{array}$ & 65 & 30 & 33 \\
\hline
\end{tabular}

Traditionally, higher education has relied on peer review and internalised procedures of quality assurance. The difficulty with these processes, from an outsider's perspective, is that it can be difficult to decipher the information and compare performance, especially internationally (Hazelkorn, 2012, p. 353; Tremblay et al., 2012 , p. 35). They also tend to be technocratic, in that they are process-driven. In contrast, rankings have succeeded because of their simplicity, but this is also their Achilles' heel; the indicators chosen are often those for which data are available rather than being a meaningful measure. For example, they use faculty/student ratio as a proxy for teaching quality even though this can have different meanings and implications for different disciplines and types of learning environments, and for public and private institutions and systems. Ultimately, this ratio may say more about available funding or the efficiency level rather than the quality of teaching and learning. Measuring employability or career readiness is also problematic; 
first-destination data capture only the first six to nine months post-graduation and are unable to distinguish between employment in 'graduate-level jobs or under-employed' (Dill \& Soo, 2005, p. 509). It is also doubtful if such information provides an accurate reflection of quality during an economic recession such as the one being experienced now.

Many of the indicators simply expose the growing wealth-gap between wellendowed selective universities and public, mass recruiting HEIs without having anything noteworthy to say about the quality of teaching-and-learning, the student experience, or research. Rather, the overemphasis on particular indicators has narrowed our understanding of the intellectual footprint of higher education across teaching, research and engagement. Yet, despite all their limitations (Hazelkorn, 2011; Rauhvargers, 2011; Marope et al., 2013), rankings have succeeded in exposing a higher education information deficit; collective anger has provoked a valuable conversation about what is 'quality' and how the value and impact of higher education are measured. Would this debate have happened anyway?

Alternatives have also emerged, part of a growing trend for 'transparency and accountability' instruments (see Box 1) (Hazelkorn, 2012; Harman, 2011). The EU commissioned U-Multirank following worries about the position of European universities (EU Presidency, 2008). In contrast to existing rankings, U-Multirank is based on principles of: i) user-driven, ii) multi-dimensional, iii) peer-group comparable, and iv) multi-level (Van Vught \& Ziegele, 2011, 2012). While it has yet to capture much interest outside Europe, policymakers see it as a valuable profiling tool (Hazelkorn, 2013b). Whatever its likelihood of overtaking the 'Big Three', its influence is evident in the way THE facilitates personalisation of rankings. OECD launched AHELO (Assessment of Higher Education Learning Outcomes), also as a riposte to rankings. Its objective is to provide a better way to assess teaching and learning outcomes, although it has run into conceptual and methodological complications and rising costs (Tremblay et al., 2012).

\section{Box 1: Typology of Transparency Instruments (alphabetical)}

- Accreditation: certifies legitimacy of a HEI or (professional) programme including the authority to award qualifications;

- Benchmarking: systematic comparison of practice and performance with peer institutions;

- Classification Systems: provides a typology or framework of HEIs to denote diversity usually according to mission and type;

- College Guides/Open Database/Social networking: fulfils public service role, putting information directly into hands of students, employers, peers and the general public;

- QA, Evaluation and Assessment: assesses institutional quality processes, or quality of research and/or teaching \& learning;

- Qualifications Frameworks: provides an integrated approach to learning, forming a single hierarchy of different qualifications, usually from primary to doctoral level;

- Rankings and Ratings: assesses performance according to particular indicators and characteristics which set a 'norm' of achievement. 
There are also specialist rankings which challenge the prevailing ethos. The Washington Monthly (US) College Guide says: 'While other guides ask what colleges can do for students, we ask what colleges are doing for the country' (Editors WM, 2005). Saviors of Our Cities: Survey of Best College and University Civic Partnerships (Dobelle, 2009) takes a similar approach, highlighting the relationship between HEIs and larger metropolitan areas. It was followed by the 2012 Metroversity Ranking (Dobelle, 2012). System-level rankings, e.g. Lisbon Council's University Systems Ranking: Citizens and Society in the Age of the Knowledge (Ederer et al., 2008), QS National System Strength Rankings (QS, 2010), and the newest Universitas 21 Rankings of National Higher Education Systems (Williams et al., 2012) all seek to measure the quality, impact and benefit of the system-as-awhole rather than as a beauty-competition between institutions. They use a broad set of indicators, such as investment, access and participation rates, contribution of higher education and research to society, internationalisation, and government policy/regulation. They raise important policy questions but so far remain peripheral.

The multiplicity of different rankings and new formats may, over time, diminish the predominance of the 'Big Three'. However, there is little evidence to-date (Dill \& Beerkens, 2010, p. 318). Eventually, open source publishing and search engines are likely to eat away at the proprietary hold that both Thomson Reuters and Scopus currently have on bibliometric data. Web tools (e.g. Google Scholar, Webometrics), Internet forums (e.g. Facebook, Rate-my-professor), and open source and digital repositories are also gaining in popularity. Australian, UK and Catalan governments, to name three, have captured the essence of these tools by creating their own public databases with detailed information about institutional performance (MyUniversity; Unistats; Winddat). And, it is not too far-fetched to imagine a higher education 'Trip Advisor' in the future. Ultimately, the real success of any format is not simply the statistical data but the added-value generated through expert data-mining and meaningful analysis - the latter being the most challenging.

\section{Policy and Institutional Changes}

While rankings have been promoted on the basis of enhancing student choice, today they signify national reputation and status in the global marketplace, as illustrated by QS' provocative ad: 'who rules' (2013a). This has encouraged a continuing fascination with the performance of the top 100 universities which, in turn, has led to a simplistic trumpeting of world-class universities as the recipe for success in the global economy. This has had a 'norming' effect on all higher education. It is not uncommon for political leaders to specify national ambitions in terms of the number of 'world-class' universities they have or want. Thus, France, Germany, Russia, Spain, China, South Korea, Taiwan, Malaysia, Finland, India, Japan, Singapore, Vietnam and Latvia, to name a few countries, have developed policies which encourage mergers between HEIs or between HEIs and research institutes, in order to create a smaller number of universities to rival the 'Ivy League' and climb in the rankings. In a European context, this has meant a move away from a traditional egalitarian approach to one which purposefully emphasises vertical or hierarchical (reputational) differentiation and leads to growing stratification between elite selective research-intensive universities and mass recruiting teaching-intensive HEIs. 
Rankings are used by governments and HEIs to strategically inform and guide policy and decision-making, explicitly identify and define national or institutional ambitions and strategies or as a benchmarking or quality assurance (QA) tool. They drive performance improvement at a national level and are used for resource allocation (Hazelkorn, 2011, p. 163). Some governments have linked rankings with accreditation or quality assessment processes, using the results to decide whether a particular HEI should be formally recognised or how it should be classified (e.g. teaching, teaching/research, research). For example, Serbia, Albania, Romania, Jordan, Macedonia and the Czech Republic use rankings to classify and/or accredit universities; Russia, Brazil, Chile, Singapore, Saudi Arabia, Kazakhstan, Mongolia and Qatar restrict state scholarships to students admitted to high-ranked universities in other countries; India, Russia and Singapore use rankings as eligibility criteria for academic collaborations (Altbach, 2012a, 2012b); Dutch (2008) and Danish (2011) immigration laws privilege foreigners who graduate from top universities (150, and 20 respectively); and the Macedonian Law on HE (2008) automatically recognises the qualifications of graduates from the top 500 HEIs. The Indian government has begun discussions with $T H E$ in order to improve their nation's standing (Nanda, 2013; Chopra, 2013) while Albania and Macedonia have invited $C H E$ and $A R W U$, respectively, to rank their HEIs (CHE, 2011; Macedonia Online, 2011). Similar effects are evident in the US, where different states use USNWR to benchmark salaries (Florida and Arizona) or as performance indicators (Minnesota, Indiana and Texas).

Yet, by appearing to address the question, 'How can our university/nation perform better?' (Marginson, 2009, p. 591), rankings have emphasised the importance of (investing in) higher education. This has been so everywhere, but especially in those regions and countries which hitherto may not have done so.

For middle-income and developing countries ... a major challenge for building and sustaining successful research universities is determining the mechanisms that allow those universities to participate effectively in the global knowledge network on an equal basis with the top academic institutions in the world. (Altbach \& Salmi, 2011, p. 1).

Over the decade, the Organisation of Islamic Countries, African Union, Association of Southeast Asian Nations (ASEAN) and Middle East and North Africa (MENA) states have developed strategies linking social and economic development with the performance and productivity of their respective higher education and research systems. The EU has adopted a similar approach, creating the European Higher Education Area and the European Research Area to bring coherence to otherwise disparate national systems, in a way which can make European higher education attractive and internationally competitive (Hazelkorn \& Ryan, 2013; Hazelkorn, 2013a).

HEIs and individual academics are not innocent victims in this process. Evidence from around the world shows how rankings continue to influence the business of higher education. While some HEIs strive to improve their standing, others simply wish to be included, as being ranked is equivalent to being visible to potential students, HE partners, policymakers, the media, etc. This explains why HEIs advertise on the web-pages of the various rankings. Thus, it is not uncommon for rankings to inform and shape institutional strategy and priorities, including international partnerships (Hazelkorn, 2011, chapt. 4), and for 
benchmarking (Proulx, 2011) (see Table III). Institutional strategic plans often make specific reference to rankings, stating that being within the top 20,50, or 100 is a key ambition. HEIs have invested considerable resources in institutional research, recruiting full-time managers to work with ranking agencies and develop appropriate strategies (Trounson, 2013), and soliciting participants for referee surveys (Jaschik, 2013). In other cases, HEIs use rankings to motivate faculty or drive change, speed-up reform or pursue a particular agenda. Because rankings reward low student/faculty ratios and research productivity, especially in the bio-sciences and medicine, institutions have changed student selection criteria and revised class sizes, set departmental targets, and merged departments. Some have prioritised or altered the balance between teaching and research, between undergraduate and postgraduate activity, and between disciplines; others have redirected resources towards knowledge fields and units more likely to succeed vis-à-vis rankings criteria. In the US, where rankings have had a longer gestation, the media is full of stories of how different universities have skewed their data on student entry tests or faculty numbers or altered their recruitment/ selection procedures to improve their position in the rankings, but there is also similar evidence from other countries (Hazelkorn, 2011).

\section{TABLE III. Indicative Actions Taken by Higher Education Institutions}

\begin{tabular}{ll}
\hline Strategy & Form task group to review and report on rankings \\
& Merge HEIs/cognate departments \\
& Establish Centres-of-Excellence \& Graduate Schools \\
& Establish Institutional Research capability \\
& Set individual targets for faculty and departments \\
Organisation & Develop/expand English-language facilities, international student facilities \\
& Professionalise Admissions, Marketing and Public Relations Advertise in \\
& Nature and Science and other high focus journals Expand internationalisation \\
& alliances and membership of global networks \\
Management & Realign resources to favour science/bio-science disciplines Positively affect \\
& student/staff ratio (SSR) \\
& Set market-based or performance/merit based salaries Create new contract/tenure \\
& arrangements Recruit/head-hunt international high-achieving/HiCi scholars Target \\
& recruitment of high-achieving students, esp. PhD Reward high-achievers and \\
& identify weak performers \\
& Enable best researchers to concentrate on research/relieve them of teaching \\
& Offer attractive merit scholarships and other benefits \\
& Discontinue programmes/activities which negatively affect performance \\
Grow postgraduate activity relative to undergraduate & Urgent faculty to increase research output, quality and citations \\
Reward faculty for publications in highly-cited journals \\
Encourage faculty to publish in English-language journals
\end{tabular}

Source: Hazelkorn, 2011.

Rankings have also underpinned or accelerated changes to academic work practices, supporting the introduction of market-based salaries with merit or performance pay and attractive packages to reward and woo high-achieving scholars. Recruitment strategies, informed by rankings data, have targeted faculty from high-ranked universities or 'capacity-building professors' on the basis that they can help improve an institution's rank. In turn, faculty are giving more consideration to the type of research they undertake and where it is published, with the emphasis on international high-impact journals rather than other formats, such as books, 
book chapters, policy reports, etc. Other evidence suggests faculty prioritise partnerships with high-ranked universities, with those HEIs reporting heightened interest in them by visiting delegations and, conversely, HEIs in developing countries saying they feel shut out.

\section{Nowhere to Hide}

Rankings started out by being about student choice but, today, they are about global and institutional positioning. What began as a small endeavour has become a profitable industry, replete with perceptions of conflict of interest and selfinterest. They cast a huge influence on higher education, in direct and indirect ways, with positive and perverse affects, amid continuing concern that they are (unintentionally) skewing policies and decisions as governments and institutions manoeuvre in choppy global waters. Many people use the expression 'rankings are here to stay'; however, it may be more appropriate to say that cross-national comparisons are 'here to stay', of which rankings are the current phenomenon.

Rankings have charmed audiences worldwide by their crude simplicity. By focusing on a limited set of attributes for which (internationally) comparable data are available, they have narrowly defined 'excellence' and 'worldclassness' with implications for nations and individual institutions, and promulgated a small set of indicators as being a meaningful, albeit unproven, measure of quality. Indeed, the difficulties encountered by both U-Multirank and AHELO highlight the complexity associated with assessing quality. Context remains fundamentally important: national and global, public or private, student cohort and learning environment can radically affect the performance of institutions and render simple comparisons meaningless. Fundamentally, rankings benefit resource-intensive institutions.

On the other hand, rankings have acted as a wake-up call for higher education, challenging self-perceptions of greatness, by nations, by institutions and by individual academics. In a global marketplace, international comparisons are inevitable, leaving no room for self-declaration. At a time of growing demand for/on higher education and rising costs, there is an emphasis on outcomes and evidence that performance measures up. By placing consideration of quality, performance and productivity within a wider comparative and global framework, rankings have taken the debate outside the traditional bailiwick of higher education and placed it firmly in the public and policy agenda. With the involvement of the EU via U-Multirank and OECD via AHELO, quality assurance has moved to the supranational level, confirming that higher education has effectively lost its role as the primary guardian of quality (Harman, 2011, p. 51; Dill \& Beerkens, 2010, pp. 313-315). Even the US, traditionally comfortable with regional accreditation processes built upon strong institutional autonomy, has moved to introduce a rating system linking performance with affordability (Anderson \& Rucker, 2013). The genie won't go back into the box.

These developments and reactions have accelerated what the EU calls the 'modernisation agenda', leading to a reshaping of institutions and systems (Ferlie et al, 2008). And, by pushing nations and HEIs to realise the strategic importance of higher education within a wider policy context, rankings have underwritten investment and spurred ambition, arguably creating a resource-intensive 'arms race' although there is little wrong with being ambitious. This has increased the sense of urgency surrounding the international debate about 'quality' as part of the 
call for greater transparency and public disclosure of student and institutional performance. Research has relied on a combination of peer review and international bibliometric indicators, but nowadays there is a deeper understanding of the breadth of/differences between disciplinary practice, and the convergence between fundamental and applied research and commercialization/knowledge transfer. At the same time, governments are asking very direct questions about the impact and relevance of publicly-funded research. This has forced higher education to engage in the conversation and identify meaningful measures which can demonstrate value and contribution rather than sit on the sidelines.

Alternative methodologies and new transparency formats have emerged, and there is growing interest in benchmarking and/or profiling tools to compare and improve/enhance performance and demonstrate distinctiveness; some governments, such as Ireland and Norway, have begun to use these tools as part of their system, (re)structuring and resourcing strategies (Salmi, 2010; van Vught et al., 2010; O'Connor, 2013; Skodvin, 2012). In the absence of credible and efficient substitutes, the emphasis and debate have focused on identifying better indicators and metrics of performance and productivity. The ground is shifting, again, between autonomy and accountability and between steering and regulation. Over time, rankings may be overtaken by social networking and online and open-source tools. These formats will put information directly into the hands of students, employers, peers and the general public, by-passing rankings, but also higher education. This is the new educational battleground.

Ellen Hazelkorn, Higher Education Policy Research Unit (HEPRU), Dublin Institute of Technology, 143-149 Rathmines Road, Dublin 6, Ireland, ellen.hazelkorn@dit.ie, www.dit.ie/researchandenterprise/meettheteam/staffprofiles/professorellenhazelkorn/

\section{NOTE}

1. The word university is used interchangeably with higher education institution (HEI) for the purposes of this article.

\section{REFERENCES}

ABS-CBN NEws (2012) Budget cuts blamed for low university rankings 09.12.12. www.abs-cbnnews.com/lifestyle/09/12/12/budget-cuts-blamed-lowuniversity-rankings

Alderman, L. \& BARbOZA, D. (2011) Europe tries to lure Chinese cash to back rescue of Euro, The New York Times 28.10.12. www.nytimes.com/2011/10/29/ world/asia/europe-seeks-chinese-investment-in-euro-rescue.html?_r=1 \&pagewanted=all

Altbach, P. G. (2012a) The globalization of college and university rankings, Change, 1, pp. 26-31.

Altbach, P. G. (2012b) Taking on corruption in international higher education, World University News, 22.07.12. www.universityworldnews.com/article .phpstory $=20120717134058780$

Altbach, P. \& SAlmi, J. (Eds) (2011) The Road to Academic Excellence: the making of world-class research universities (Washington, D.C., World Bank).

ANDERSON, N. \& RUCKER, P. (2013) Obama proposes college-rating system that could increase affordability, Washington Post, 22.08. www.washingtonpost 
.com/politics/obama-to-propose-college-ranking-system-that-could-increase -affordability/2013/08/22/73e674c0-0b17-11e3-b87c-476db8ac34cd_story.html ANON (2012) Irish universities lose ground in world rankings, Public Affairs Ireland 11.9.12 www.publicaffairsireland.com/news/1165-irish-universities-lose-ground -in-world-rankings

Billal, F. (n/a) Academic Ranking of Universities-Healthy Competition, Setting Hierarchy or Intelligent Marketing? www.unesco.org/new/fileadmin/MULTI MEDIA/HQ/ED/pdf/RANKINGS/Ranking\%20of\%20universities_\%20Paris 2011.pdf

Böhm, A, Davis, D., Meares, D. \& Pearce, D. (2002) Global Student Mobility 2025: forecast of the global demand for international higher education (Australia, IDP Education). http://www.aiec.idp.com/pdf/Bohm_2025media_p.pdf

CHE (2011) Greater Transparency in the Albanian Higher Education Sector. 15.07.11. www.ireg-observatory.org/index.php?option=com_content\&task=view\&id $=152 \&$ Itemid $=1$

CHOPRA, R. (2013) Govt [sic] seeks external push for varsities' global ranking, dna, 14.05 .

DANIEL, J. (1996) The world cuisine of borderless knowledge, Times Higher Education 09.08.96 www.timeshighereducation.co.uk/story.asp?storyCode $=99628 \&$ sectioncode $=26$

Dempsey, N. (2004) Address at the Europe of Knowledge 2020 Conference. Liege.

Dill, D. D. \& BeERKENS, M. (2010) Reflections and conclusions, in: D. DILL \&. M. Beerkens (Eds) Public Policy for Academic Quality. Analyses of Innovative Policy Instruments (Dordrecht, Springer) pp. 313-335.

Dill, D. D. \& Soo, M. (2005) Academic quality, league tables and public policy: a cross-national analysis of university ranking systems, Higher Education, 49, pp. $495-537$.

Dobelle, E. S. (2009) Saviours of Our Cities: 2009 Survey of College and University Civic Partnerships. www.wsc.ma.edu/Announcements/SOOC $\% 20$ Survey $\% 20$ Overview.pdf; www.wsc.mass.edu/Announcements/PRtop25.pdf

DobELLE, E. S. (2012) Metroversities: a 2012 ranking of metroversity-impacted urban areas (Westfield, MA). www.evandobelle.com/MetroversitySurvey.pdf

EDERER, P., SCHULER, P. \& WILLS, S. (2008) University Systems Ranking: citizens and society in the Age of the Knowledge. www.lisboncouncil.net/publication/ publication/38-university-systems-rankingcitizens-and-society-in-the-age-ofknowledge.html

EDITORS WM (2005) The Washington Monthly College Guide. www.washington monthly.com/features/2005/0509.collegeguide.html

EHRENBERG, R. G. (2001) Reaching for the brass ring: how the U.S. News E World Report rankings shape the competitive environment in U.S. higher education, The Review of Higher Education, 226.

EU PRESIDENCY, EUROPEAN UNION (2008) International Comparison of Education Systems: a European model. www.eu2008.fr/PFUE/lang/en/accueil/PFUE -11_2008/PFUE-13.11.2008/comparaison_internationale_des_systemes _educatifs_un_modele_europeen.html

EUROPA (2011) Supporting growth and jobs - an agenda for the modernisation of Europe's higher education systems. Communication from the Commission to the European Parliament, The Council, The European Economic and Social Committee and the Committee of the Regions (Brussels). 
Ferlie, E., Musselin, C. \& Andresani, G. (2008) The steering of higher education systems: a public management perspective. Higher Education, 56, pp. 325-348.

GutTenPlan, D. D. (2012) Ratings at a price for smaller universities, New York Times. 30.12.

HARMAN, G. (2011) Competitors of rankings: new directions in quality assurance and accountability, in: J. C. SHIN, R. K. TOUTKOUSHIAN \& U. TEICHLER (Eds) University Rankings. Theoretical Basis, Methodology and Impacts on Global Higher Education (Dordrecht, Springer).

HAZELKORN, E. (2011) Rankings and the Reshaping of Higher Education: the battle for world class excellence (Basingstoke, Palgrave-MacMillan).

HAZELKORN, E. (2012) European 'transparency instruments': driving the modernisation of European higher ducation, in: P. SCOTT, A. CURAJ, L. VLĂSCEANU \& L. WILSON (Eds) European Higher Education at the crossroads: between the Bologna Process and national reforms vol. 1. (Dordrecht, Springer) pp. 339-360.

HAZELKORN, E. (2013a) Striving for 'World Class Excellence': rankings and emerging societies, in: A. ARAYA \& P. MARBER (Eds) Higher Education in the Global Age: universities, interconnections and emerging societies (London, Routledge).

HAZELKORN, E. (2013b) Europe enters the college ranking game, Washington Monthly, September/October. www.washingtonmonthly.com/magazine/september _october_2013/features/europe_enters_the_college_rank046894.php

HAZELKORN, E. \& RYAN, M. (2013) The impact of university rankings on higher education policy in Europe: a challenge to perceived wisdom and a stimulus for change, in: P. ZGAGA, U. TEICHLER \& J. BRENNAN (Eds) The Globalization Challenge for European Higher Education: Convergence and Diversity, Centres and Peripheries (Frankfurt, Peter Lang).

IREG (2011) IREG Ranking Audit Manual (Brussels).

JASCHIK, S. (2013) Rigging the rankings? Inside Higher Ed 08.04. www.inside highered.com/news/2013/04/08/irish-university-tries-recruit-voters-improve -its-international-ranking

KISHKOVsKY, S (2012) Russia moves to improve its university ranking, The New York Times. 05.03.12. www.nytimes.com/2012/03/26/world/europe/russia -moves-to-improve-its-university-rankings.html?pagewanted=all

KNIGHT, J. (2011) Education hubs: a fad, a brand, an innovation? fournal of Studies in International Education, 15, pp. 221-240.

KNOBEL, M. (2011) Internationalizing Brazil's Universities: creating coherent national policies must be a priority. Research \& Occasional Paper Series (Berkeley, University of California).

LaU, J. H-C (2012) Asian Colleges Gaining Respect, Report Finds, 18.03.12. www.nytimes.com/2012/03/19/world/asia/asian-colleges-gaining-respectreport-finds.html

LEAHY, J. (2012) BRICS to debate creation of common bank, Financial Times, 20.03 .

LI, M., SHANKAR, S. \& TANG, K. K. (2011b) Catching up with Harvard: results from regression analysis of world university league tables, Cambridge fournal of Education, 41, pp. 121-137.

LIU, N. C. \& CHENG, Y. (2005) Academic ranking of world universities methodologies and problems, Higher Education in Europe, 30, pp. 127-136. 
MACEDONIA ONLINE (2011) Shanghai University to Rank Macedonian Universities. 16.01.11 http://macedoniaonline.eu/content/view/17372/45

MARGINSON, S. (2009) University rankings, government and social order: managing the field of higher education according to the logic of the performative present-as-future, in: M. SimONS, M. OLSSEN \&. M. PETERS (Eds) Re-reading Education Policies: studying the policy agenda of the 21st century (Rotterdam, Sense) pp. 584-604.

Marope, P. T. M., Wells, P. J. \& Hazelkorn, E. (2013) Rankings and Accountability in Higher Education (Paris, UNESCO).

MARSZAL, A. (2012) University rankings: top British universities on the rise, The Telegraph 11.09.12. www.telegraph.co.uk/education/universityeducation/ 9535071/University-rankings-British-universities-on-the-rise.html

NANDA, P. K. (2013) India to lobby foreign agencies for improving university rankings, Live Mint 22.05.

OECD (2009) Crisis bites deeper, OECD Observer 25.03.09. www.oecdobserver .org/news/fullstory.php/aid/2871/News_brief-April_2009.html

O'ConNor, M. (2013) Transparency and the Advancement of Knowledge. EU Presidency Higher Education Conference, Dublin.

PROULX, R. (2011) Using world university ranking to inform and guide strategic policy making: a case study of a Canadian research university, in: K. YU \& A. L. STITH (Eds) Competition and Cooperation among Universities in the Age of Internationalization (Shanghai, Shanghai Jiao Tong University) pp. 151-168.

RAUHVARGERS, A. (2011) Global University Rankings and Their Impact. Report I (Brussels, EUA).

RAUHVARGERS, A. (2013) Global University Rankings and Their Impact. Report II (Brussels, EUA).

Ritzen, J. (2010) A Chance for European Universities (Amsterdam, University Press).

SALMI, J. (2010) Beyond rankings: towards benchmarking of tertiary education systems, Bridges, 26, July.

SHARMA, Y. (2010) Asia: universities' rise beginning to eclipse US, World University News 21.11.10. www.universityworldnews.com/article.php?story $=20101120000653689$

Sharma, Y. (2013) Darts and sciences, South China Morning Post 15.09.13. www.scmp.com/lifestyle/family-education/article/1213101/darts-and-sciences

SilversteIn, M. J. \& SINGHI, A. (2012) Can U.S. universities stay on top? India and China are still far behind in elite education, but they are scrambling to catch up, Wall Street fournal, 28.09.12.

SkodvIN, O-J. (2012) How to measure institutional profiles in the Norwegian HE landscape: the Norwegian 'Institutional Profile project', in: P. SCOTT, A. CURAJ, L. VLĂSCEANU \& L. WILSON (Eds) European Higher Education at the crossroads: between the Bologna Process and national reforms, vol. 2 (Dordrecht, Springer) pp. 905-934.

Times Higher EdUCATION (2012) My university is world-class because. . . www.timeshighereducation.co.uk/hybrid.asp?typeCode $=684 \&$ pubCode $=1$ \&navcode $=175$

Times Higher EDUCATION (2013) World University Rankings video competition. http://www.timeshighereducation.co.uk/news/world-university-rankingsvideo-competition/2003229.article 
Tremblay, K., Lalancette, D. \& Roseveare, D. (2012) Assessment of Higher Education Learning Outcomes. Feasibility Study Report. Vol. 1 - Design and Implementation (Paris, OECD).

Trounson, A. (2013) Universities hire rankings pros, Inside Higher Ed 20.03.13.

UNESCO (2009) Global Education Digest (Paris, UNESCO). www.uis.unesco.org/ Library/Documents/ged09-en.pdf

UNITED NATIONS (2011a) World Economic Situation and Prospects 2012 Global economic outlook. www.un.org/en/development/desa/policy/wesp/wesp_current/ 2012wesp_prerel.pdf

UNited NATIONS (2011b) World Population Prospects. The 2010 Revision. Highlights and Advance Tables. http://esa.un.org/wpp/Documentation/pdf/WPP2010 _Highlights.pdf

Van Vught, F. A. \& Ziegele, F. (Eds) (2011) Design and Testing the Feasibility of a Multidimensional Global University Ranking Final Report. http://ec.europa.eu/ education/higher-education/doc/multirank_en.pdf

Van Vught, F. A. \& ZIEGele, F. (Eds) (2012) Multidimensional Ranking. The Design and Development of U-Multirank (Dordrecht, Springer).

van Vught, F. A., Kaiser, F., File, J. M., Gaethgens, C., Peter, R. \& Westerheijden, D. F. (2010) U-Map. The European Classification of Higher Education Institutions (Enschede, University of Twente).

WADE, R. H. (2011) Emerging world order? From multipolarity to multilateralism in the G20, the World Bank, and the IMF, Politics and Society, 39, pp. 347-378.

Webster, D. S. A. (1986) Academic Quality Rankings of American Colleges and Universities (Springfield, Charles C. Thomas).

Williams, R., DE Rassenfosse, G., Jensen, P. \& MARginson, S. (2012) U21 Rankings of National Higher Education Systems. www.universitas21.com/news/ details/61/u21-rankings-of-national-higher-education-systems-2012

\section{Webography}

My University http://myuniversity.gov.au/

Catalan university performance http://winddat.aqu.cat/

QS World University Rankings, 2013a http://www.topuniversities.com/universityrankings

QS Work Ranking by Subject, $2013 b$ http://www.topuniversities.com/subjectrankings

QS (2010): THE QS Top Universities: National System Strength Rankings http:// www.topuniversities.com/university-rankings/worlduniversity-rankings/ methodology/safe

Unistats http://unistats.direct.gov.uk/ 